\title{
Application of HEC-HMS for the Assessment of Water Availability in Fincha and Didessa Sub-basin, Ethiopia
}

\author{
Jemal Ibrahim Mohammed* Amayou Belissa Fuli \\ Hydraulic and Water Resources Engineering, Institute of technology, \\ Wollega University, Nekemte, Ethiopia
}

\begin{abstract}
The water resources availability assessment required for determination of optimal allocation and planning of water resources. This study is mainly focus on the water resources availability in the Fincha and Didessa sub-basin of Ethiopia by using HEC-HMS. The performance of the model was assessed via calibration at gauging station using Relative Volume Error (D), coefficient of determination $\left(\mathrm{R}^{2}\right)$ and Nash-Sutcliffe Efficiency (NSE) performance coefficients. Then the model was validated using the parameters optimized during model calibration. The availability of water resources assessed at different watershed created to see at local level and finally at outlet point to Main River for each sub-basin separately. The HEC-HMS model shows a good performance Little anger which resulted $\mathrm{D}=2.58, \mathrm{R}^{2}=0.75$ and $\mathrm{NSE}=0.63$ during calibration and $\mathrm{D}=4.32, \mathrm{R}^{2}=0.77$ and $\mathrm{NSE}=0.46$ during validation and Neshi $\mathrm{D}=-1.37, \mathrm{R}^{2}=0.53$ and $\mathrm{NSE}=0.58$ during calibration and $\mathrm{D}=6.98, \mathrm{R}^{2}=0.68$ and $\mathrm{NSE}=0.58$ during validation for Didessa and Fincha Sub basin respectively. The parameters optimized at little Anger and Neshi gauging station was used for flow simulation to assess water resources availability on monthly and annual basis. The flow components were also separated at small catchment considered for all sub-basin. The result shows that high percentage of flow occupied by Direct Runoff for both Didessa and Fincha sub basins. So the available water in the sub-basins should be allocated fairly and accurately for water resources projects for effective utilization of the country water resources.
\end{abstract}

Keywords: Fincha and Didessa sub-basin, HEC-HMS, Water Resources Availability.

DOI: $10.7176 / \mathrm{JEES} / 10-11-05$

Publication date: November $30^{\text {th }} 2020$

\section{INTRODUCTION}

1.1 General

The water resources availability assessment requires detailed insights into hydrological processes. However, studying the complexity of hydrological processes, needed for sustainable sub-basin management, is basically based on understanding rainfall characteristics and Sub-basin properties, for which rainfall-runoff modeling studies are useful. Rainfall-runoff models have been widely used in hydrology over the last century for a number of applications and play an important role in in optimal planning and management of water resources in basin (Makkeasorn, 2008).

The availability of adequate fresh water is a fundamental requirement for the sustainability of human and terrestrial landscapes. Thus, the importance of understanding and improving predictive capacity regarding all aspects of the global and regional water cycle is certain to continue to increase. One fundamental component of the water cycle is streamflow. Thus forecasting stream flow under climate change is very indispensable (Makkeasorn, 2008).

As a significance, Water resources planning and management efficacy is subject to capturing inherent uncertainties stemming from climatic and hydrological inputs and models. Water availability is critical in reservoir operation and water allocation decision making, fundamentally contain uncertainties arising from assumed initial conditions, model structure, and modeled processes

Therefore the assessment of water availability will play great role to handle problems of water allocation in the selected sub-basins. The main objectives of this research are to analyse the spatial variation of the runoff generation characteristics of Fincha and Dideesa sub-basins using a semi-distributed hydrological model and to simulated water budget components (determination of water availability at local catchment level) depending on the importance of catchment area.

\section{DESCRIPTION OF STUDY AREA}

\subsection{General Features}

The Blue Nile Basin (Abbay basin) is generally divided into 14 Sub-basins according to their configuration in topology (MoWR, 2002). This Research highly emphasis on the availability of water in Fincha and Didessa Subbasin. Table 1 shows the catchment area, Mean annual rainfall and mean annual flow of Fincha and Didessa Subbasin. 
Table 1: catchment area, Mean annual rainfall and mean annual flow of Fincha and Didessa Sub basin (Wondye, 2009)

\begin{tabular}{|c|c|c|c|c|c|c|}
\hline S.No & Sub-basin & $\begin{array}{l}\text { Catchment } \\
\left(\mathrm{km}^{2}\right)\end{array}$ & area & $\begin{array}{l}\text { Mean } \\
(\mathrm{mm})\end{array}$ & annual rain fall & $\begin{array}{l}\text { Mean annual flow } \\
\qquad\left(\mathrm{Mm}^{3}\right)\end{array}$ \\
\hline 1 & Fincha & 4089 & & 1766 & & 1719 \\
\hline 2 & Dedessa & 27531 & & 1308 & & 8028 \\
\hline
\end{tabular}

\subsection{Fincha Sub basin}

The altitude in Fincha sub basin ranges approximately between 880masl and 3200masl. The sub basin has an annual rainfall ranging between $960 \mathrm{~mm}$ and $1835 \mathrm{~mm}$ (Awulachew, 2009), Whereas the annual maximum and minimum temperature in the sub basin varies between $19.5^{\circ} \mathrm{C}-31.5^{\circ} \mathrm{C}$ and $6^{\circ} \mathrm{C}-16^{\circ} \mathrm{C}$ respectively. (Awulachew, 2009). Potential Evapotranspiration (PET) in the sub basin is generally between $1365 \mathrm{~mm}$ and $1970 \mathrm{~mm}$ per year (Awulachew, 2009). The land use in sub basin is dominated by cultivation and irrigated agriculture. Pastoral land is also practiced in northern parts of the sub basin (Awulachew, 2009).

\subsection{Didessa Sub basin}

The altitude in Didessa sub basin ranges approximately between 630masl and 3130masl. (Awulachew, 2009). The sub basin has an annual rainfall ranging between $1200 \mathrm{~mm}$ and $2200 \mathrm{~mm}$ (Awulachew, 2009), whereas the annual maximum and minimum temperature in the sub basin varies between $20^{\circ} \mathrm{C}-33^{\circ} \mathrm{C}$ and $6.5^{\circ} \mathrm{C}-19^{\circ} \mathrm{C}$ respectively. Potential Evapotranspiration (PET) in the sub basin is generally between $1340 \mathrm{~mm}$ and $1980 \mathrm{~mm}$ per year. The Didessa sub basin is dominated by woodlands (Awulachew, 2009).

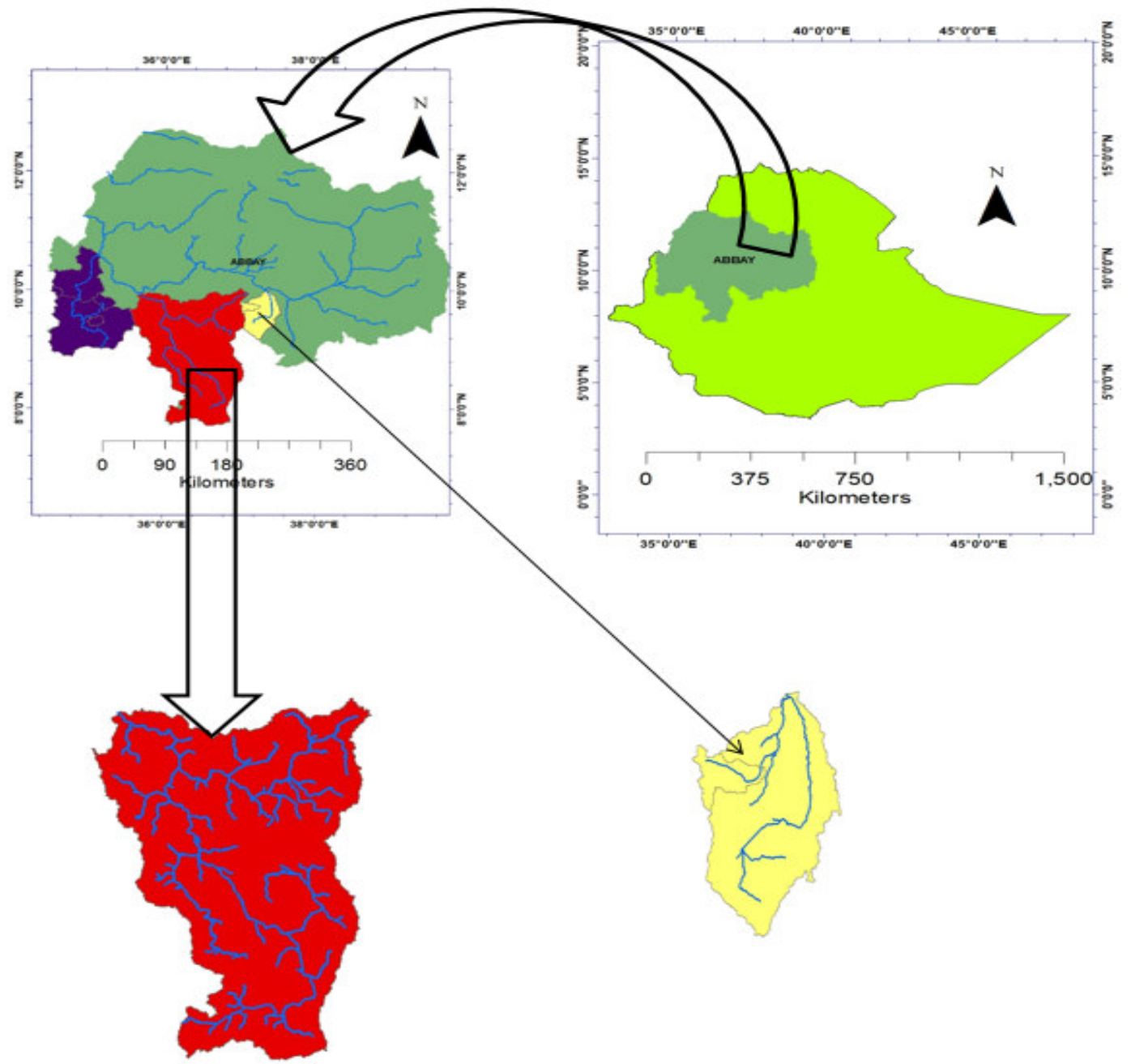

Figure 1: Location of Fincha and Didessa Sub-basin. 


\section{MATERIALS AND METHODS}

\subsection{Materials}

The materials used in the research to achieve the objectives of the study were DEM data, Arc GIS 10.5, HECGeoHMS, HEC-HMS, HEC-DSSve2.01, ETo Calculator and Spread Sheet/ Microsoft Excel.

\subsection{Methodology}

As any research requires clear methodology, the methodology we used in this research work includes the following steps (1) Data collection; (2) Meteorological and Hydrological Data analysis (3) Watershed-based hydrological modeling; (4) Water availability assessment through model calibration and validation; (5) Flow component Separation

\subsubsection{Meteorological and Hydrological Data analysis}

\section{Filling missed data}

Stations with missing data were filled by appropriate method of filling missed data, in this research simple linear interpolation and normal ratio method were used.

Normal ratio methods are expressed by the following relationship.

$\mathrm{P}_{\mathrm{x}}=\frac{\mathrm{N}_{\mathrm{X}}}{\mathrm{N}}\left(\frac{\mathrm{P}_{1}}{\mathrm{~N}_{1}}+\frac{\mathrm{P}_{2}}{\mathrm{~N}_{2}}+\cdots \cdots \cdots+\frac{\mathrm{P}_{\mathrm{n}}}{\mathrm{N}_{\mathrm{n}}}\right)$

Where,

$P_{x}=$ Missing value of precipitation to be computed.

$\mathrm{N}_{\mathrm{x}}=$ Average value of rainfall for the station in question for recording period.

$\mathrm{N}_{1}, \mathrm{~N}_{2} \ldots \ldots \ldots . . \mathrm{Nn}=$ Average value of rainfall for the neighboring station.

$\mathrm{P}_{1}, \mathrm{P}_{2} \ldots . \mathrm{P}_{\mathrm{n}}=$ Rainfall of neighboring station during missing period

$\mathrm{N}=$ Number of stations used in the computation.

Filling of missing temperature, humidity, sunshine, wind speed data was done with the same procedure and method as precipitation data.

Finally Meteorological data test were conducted for stationarity, consistency, and homogeneity to accept the data for further implementation.

\section{Hydrological Data Analysis}

The stations found in the sub basin have record gap so filling in missing data and Extension of data was carried out using linear regression analysis method from the station with full record.

\section{Areal Precipitation}

To estimate areal precipitation Thiessen polygon method was used due to the large differences in the catches at the rain gauges and non-uniformly distribution of the rain gauges throughout the study areas.

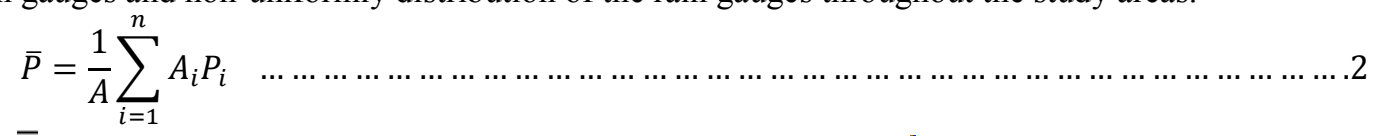

Where, $\bar{P}=$ Areal average rainfall, $\mathrm{Pi}=$ Rainfall measured at station i, $A_{i}=$ Area of sub-region of $\mathrm{i}$ station and $\mathrm{A}$ $=$ total area of sub-basin

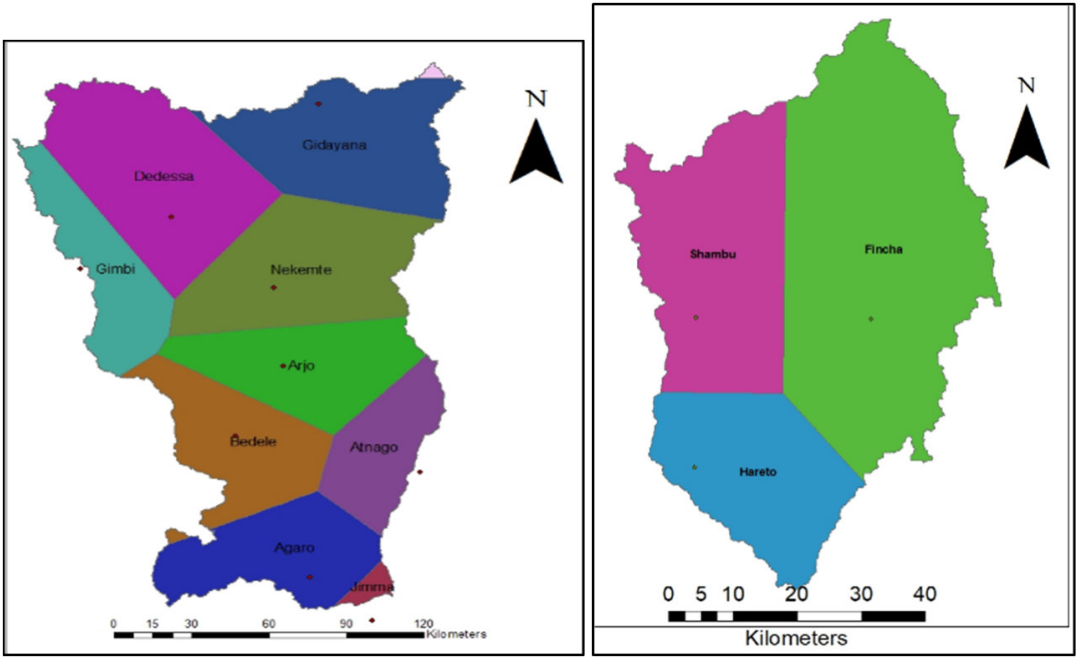

Figure 2: Thiessen polygon of Didessa and Fincha sub-basins Meteorological stations. 
Generally the overall procedure that followed in the research work is as given in figure 3 .

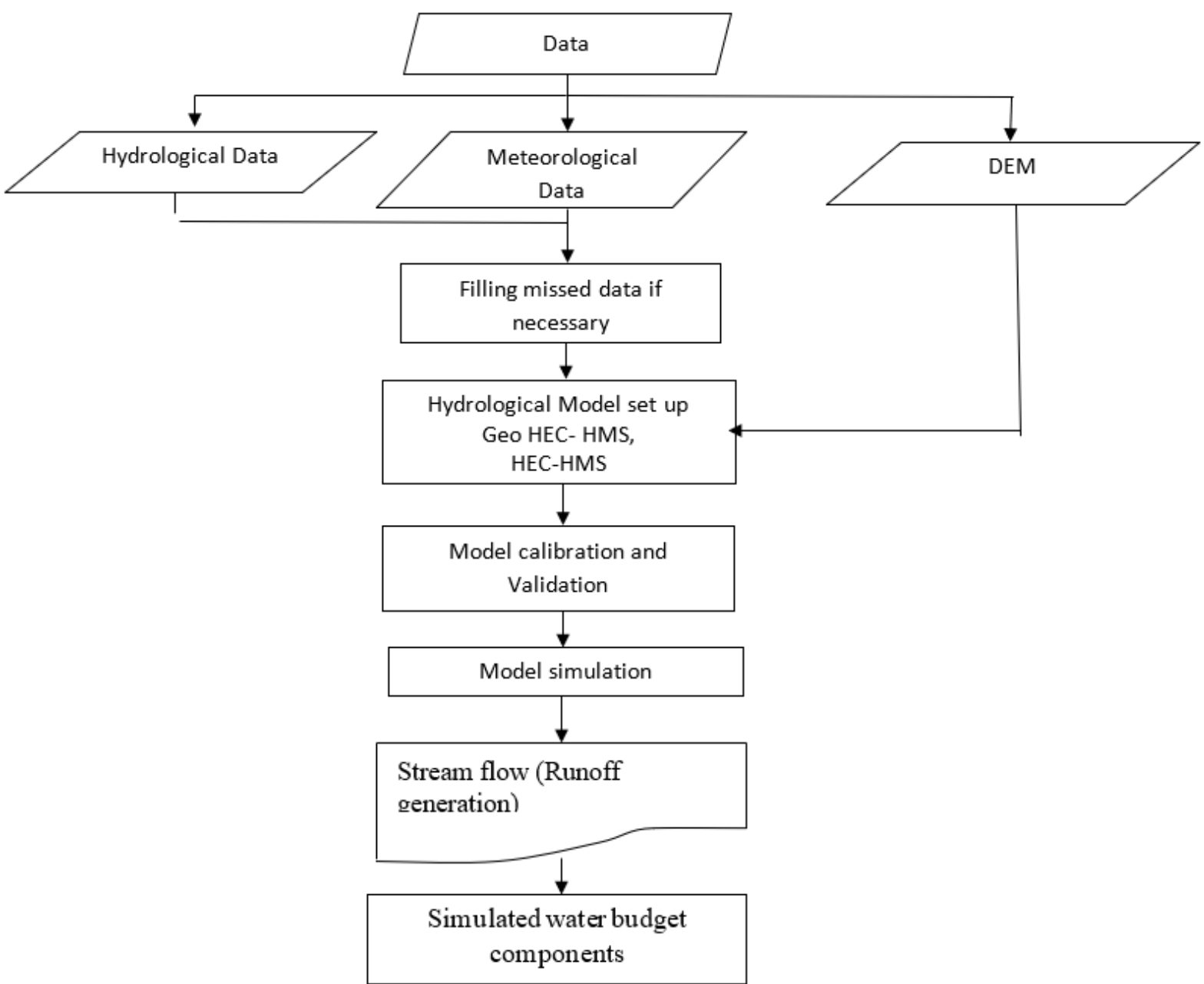

Figure 3: Methodology used for the research

\subsubsection{Watershed-based hydrological modeling}

\subsubsection{HEC-GeoHMS Setup and Catchment processing}

The major steps in HEC-GeoHMS processes include: terrain preprocessing, hydrologic processing, basin processing, stream and watershed characteristics, and hydrologic parameters and HEC-HMS model files. The results of terrain preprocessing were shown in Figure 4 and 5 for Fincha and Didessa sub-basins respectively. 


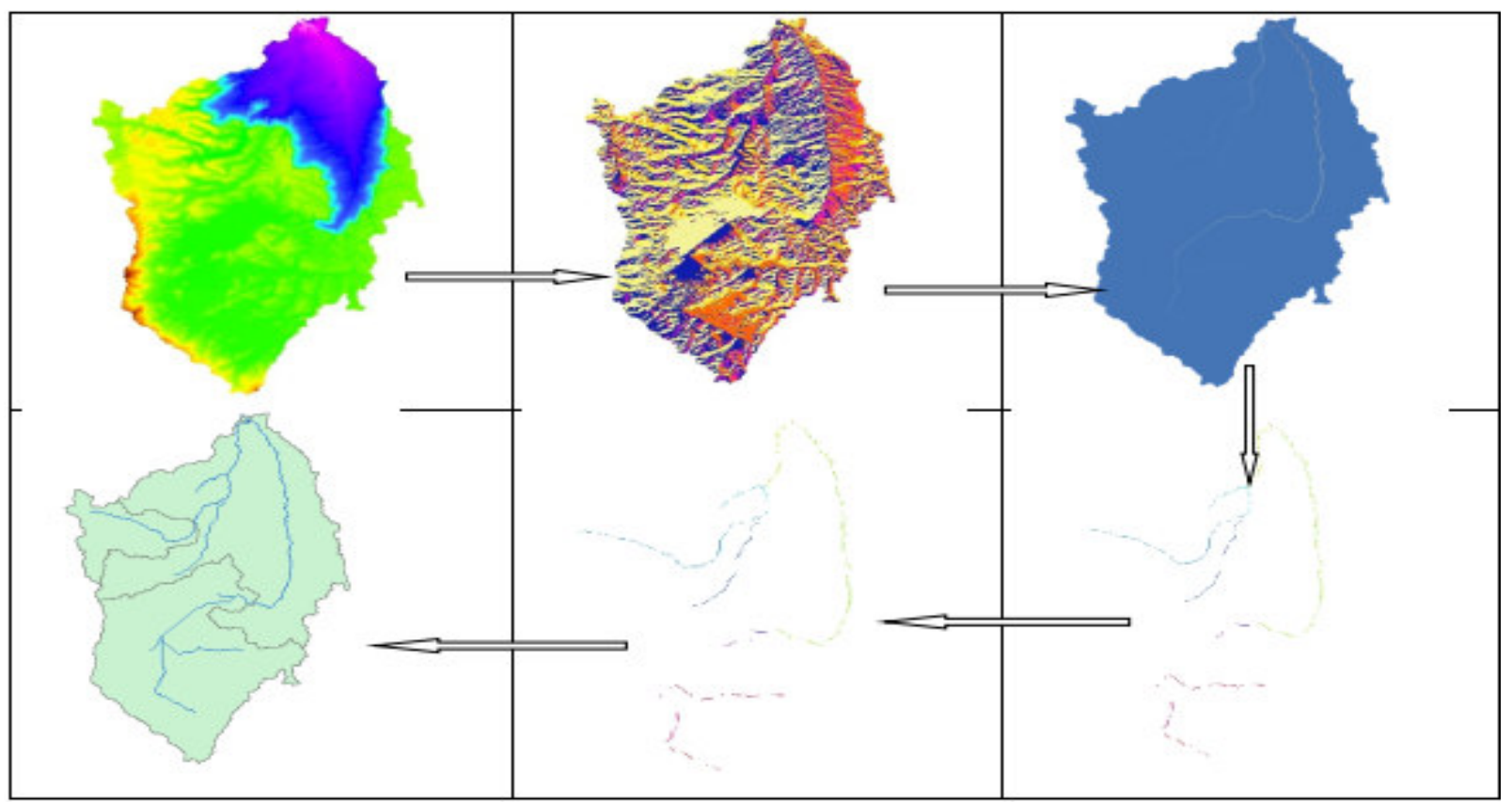

Figure 4: HEC-GeoHMS Terrain Processing of Fincha sub basin.

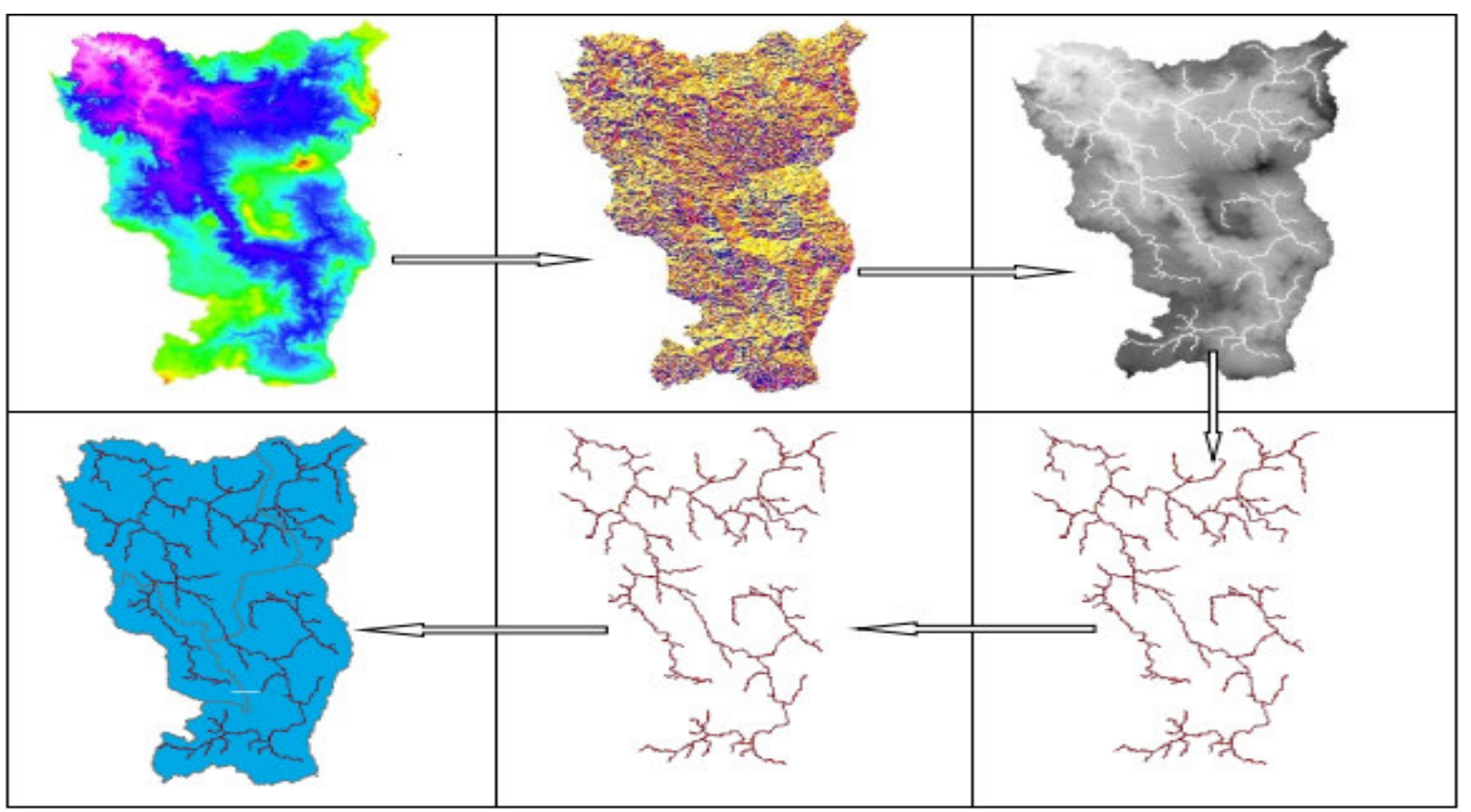

Figure 5: HEC-GeoHMS Terrain Processing of Didessa sub basin 

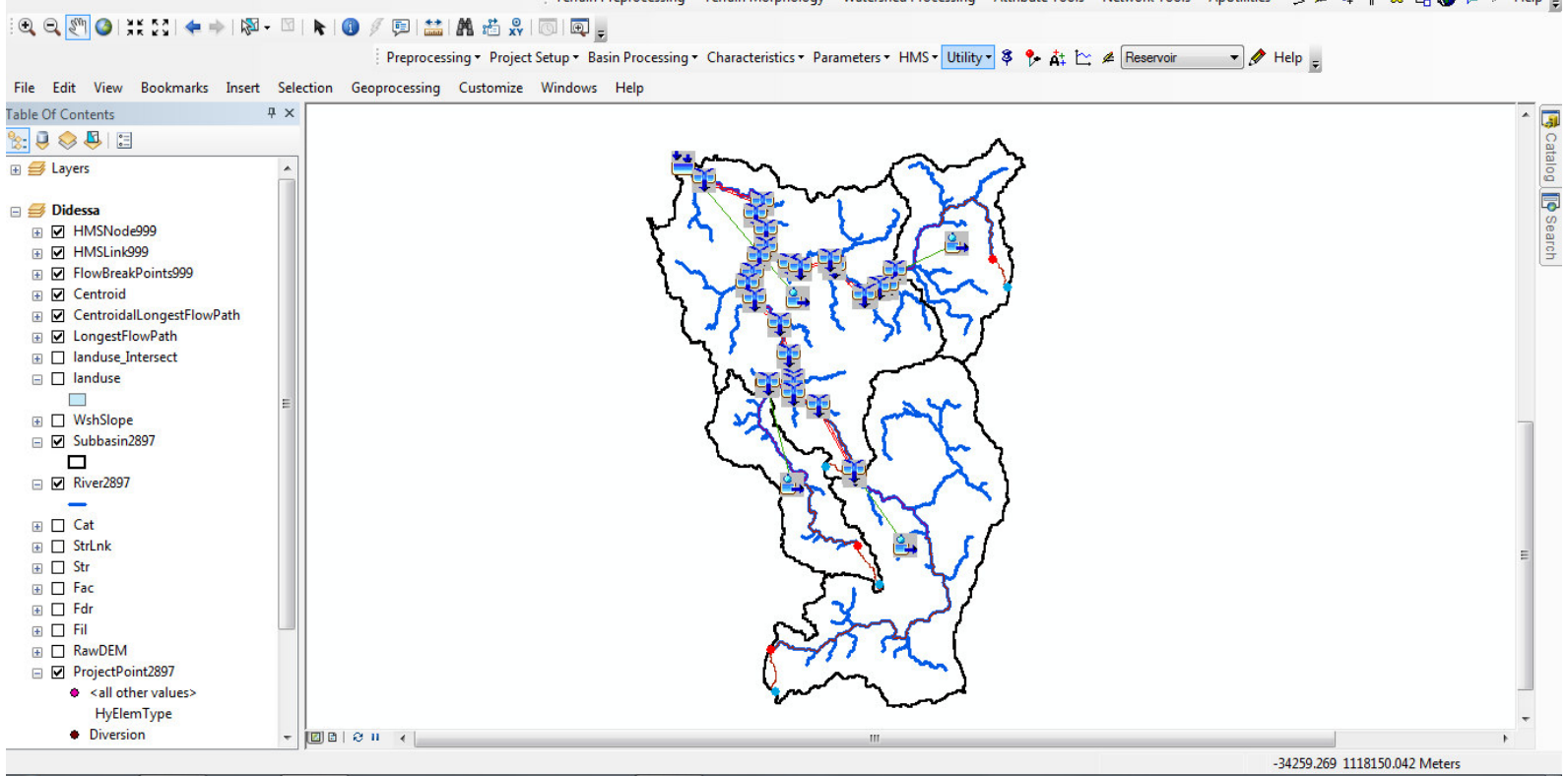

HEC-HMS Setup and Data preparation

Figure 6: HEC-GeoHMS Background map of the Didessa sub basin.

\section{Basin Models}

HMS model components include basin models, meteorologic models, control specifications, and input data. A simulation calculates the precipitation-runoff response in the basin model given input from the meteorologic model. The control specification defines the time period and time step of the simulation run. Input data is required as parameter or boundary conditions in basin and meteorologic models.

Basin model is responsible for describing the physical properties of the watershed and the topology of the stream network. It contains the modeling components that describe infiltration, surface runoff, base flow, and channel routing. Their principle purpose is to convert atmospheric conditions in to streamflow at specific locations in the watershed. Hydrologic elements (sub basin, junctions, sources, sinks, reservoirs, and diversions) are connected together in a dendritic network to form a representation of the stream system. In this study case, as described so far, the basin model is created by HEC-GeoHMS and has been imported here to HEC-HMS which illustrated below (Figure 7,8).

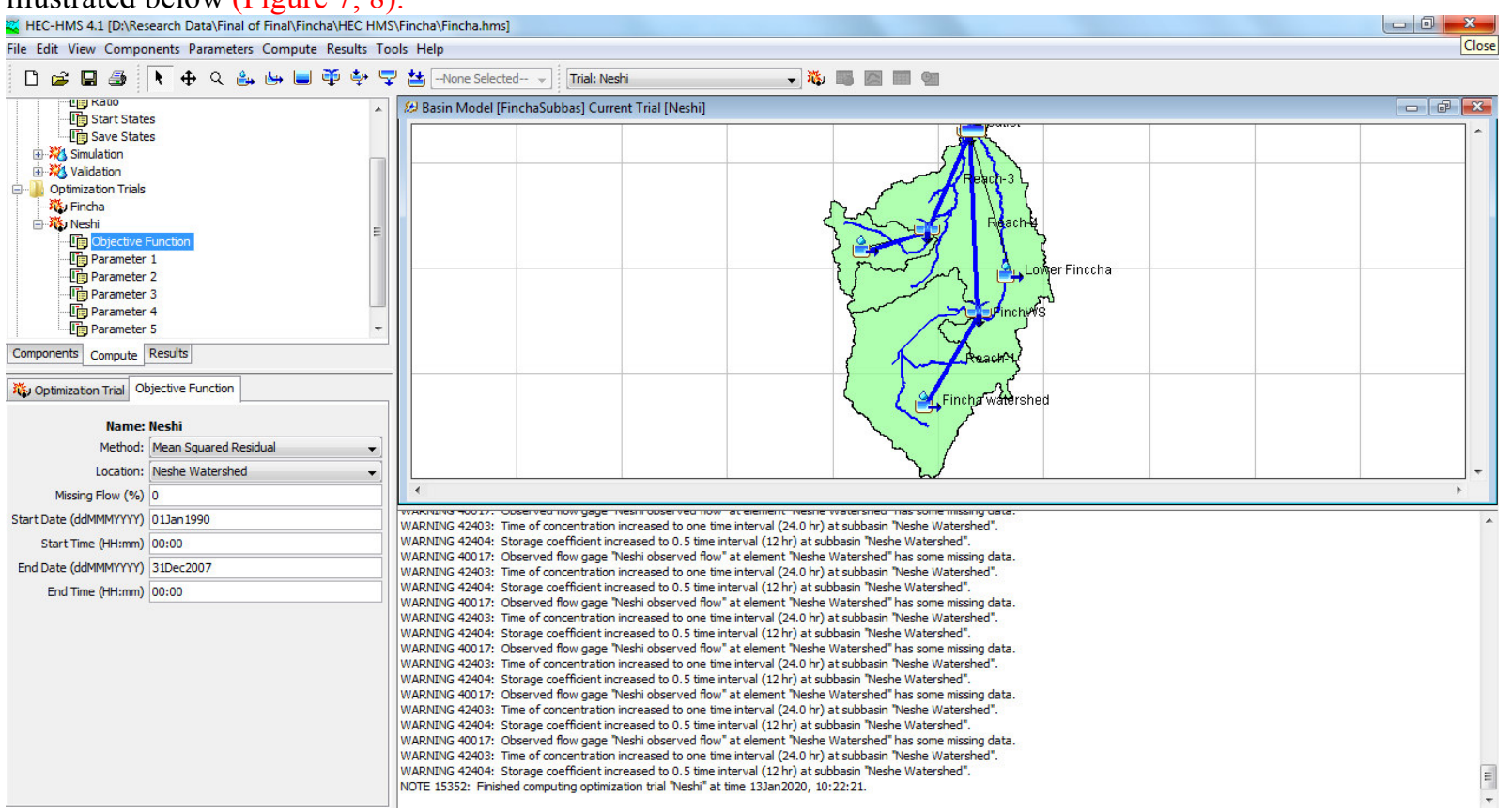

Figure 7: Fincha SubBasin model created by HEC-GeoHMS and imported to HEC-HMS model 


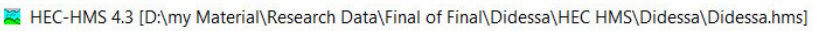

File Edit View Components GIS Parameters Compute Results Tools Help

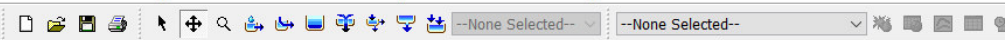

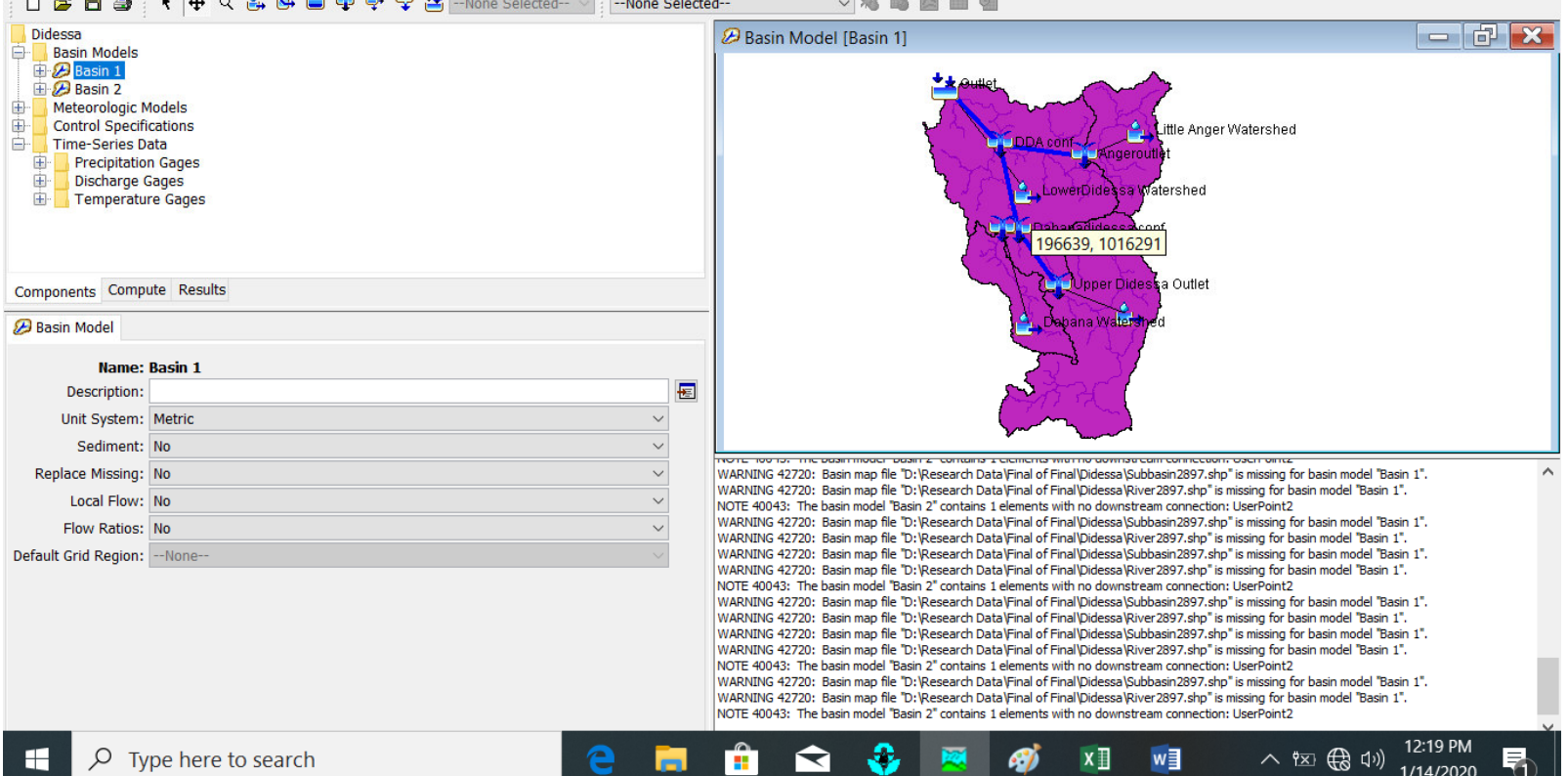

Figure 8: Didessa SubBasin model created by HEC-GeoHMS and imported to HEC-HMS model

\section{Parameter Estimation}

In HEC-HMS model a process called optimization (calibration) is used for parameter estimation.

In this particular study the Univariate-Gradient Algorithm search method and the sum of squared residuals measure for goodness of fit were applied.

\section{Analytical Components of HEC-HMS}

HEC-HMS consists of separate models of the major hydrological processes and transports. It consists of runoff volume models, models of direct runoff (overland flow and interflow), base flow models, channel flow models. So the analytical components of HEC-HMS used for this particular research were summarized by table 2 .

Table 2: Model selected for analytical components

\begin{tabular}{ll} 
Analytical Components & Selected Model \\
Loss Model & deficit and constant-rate loss model \\
Transform Models & Clark Unit Hydrograph Transform \\
Base Flow Models & Monthly constant \\
Routing Models & Muskingum route \\
\hline
\end{tabular}

Clark Unit Hydrograph Transform

Application of the Clark model requires: properties of the time-area histogram and the storage coefficient, $R$.

That typical time area relationship, which is built into the program, is:-

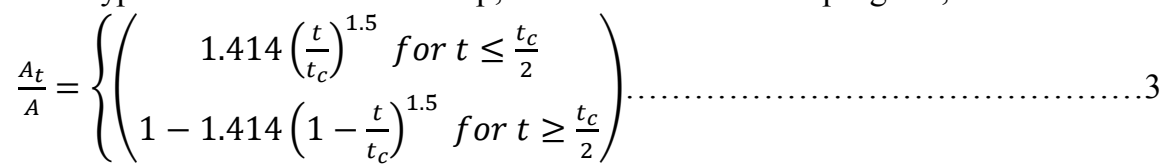

Where $A t=$ cumulative watershed area contributing at time $t ; A=$ total watershed area; and $\mathrm{t}_{\mathrm{c}}=$ time of concentration of watershed.

\section{Muskingum route}

The Muskingum routing method uses simple conservation of mass approach to route flow through the stream reach. The Muskingum $\mathrm{K}$ is the travel time through the reach. The Muskingum $\mathrm{X}$ is the weighting between inflow and outflow influence; it ranges from 0 to 0.5 . This model uses a simple finite difference approximation of the storage continuity equation. Storage is modeled as the sum of prism storage and wedge storage. According to Muskingum, storage is expressed as;

$S_{t}=K O_{t}+k X\left(I_{t}-Q_{t}\right)=K\left[X I_{t}-(1-X) Q_{t}\right]$ .. .4

Where $\mathrm{K}=$ travel time of the flood wave through routing reach; and $\mathrm{X}=$ dimensionless weight, $\mathrm{X}$ ranges 0 up to 0.5 . The quantity on the right hand side is weighted discharge. Generally the routed out flow of a given reach is estimated by the following equation,

$$
O_{t}=\left\langle\frac{\Delta \mathrm{t}-2 \mathbf{k x}}{2 k(1-k)+\Delta \mathrm{t}}\right\rangle I_{t}+\left\langle\frac{\Delta \mathrm{t}+2 \mathbf{k x}}{2 k(1-x)+\Delta \mathrm{t}}\right\rangle I_{t-1}+\left\langle\frac{2 \mathrm{k}(1-\mathrm{x})-\Delta \mathrm{t}}{2 k(1-k)+\Delta \mathrm{t}}\right\rangle \boldsymbol{O}_{t-1} \ldots \ldots \ldots \ldots \ldots \ldots \ldots .5
$$




\subsubsection{Water Availability Assessment}

\subsubsection{HEC-HMS Model Calibration and Validation}

The latest version of HEC-HMS (4.3) model includes optimization manager that allows automated model calibration (Conway, 2004).

In this study Sum of squared residuals function (SSR) with Nelder and Mead Method (NM) was used to search optimal parameter value since it can possible to optimize several parameters simultaneously.

A total of 10 years historical data from 1991 to 2000 was used for calibration, 5years was used for validation (2001-2005) Fincha sub-basins. But for Didessa sub-basin 7years historical data was used for calibration and 5 years data was used for validation

\subsubsection{HEC-HMS Model Performance}

The performance of the model was evaluated by Nash and Sutcliffe efficiency criteria (NSE), coefficient of determination $\left(\mathrm{R}^{2}\right)$, and Percent difference/Relative Volume Error (D).

\section{Nash-Sutcliffe Efficiency, NSE}

The Nash and Sutcliffe coefficient (NSE) is a measure of efficiency that relates the goodness-of-fit of the model to the variance of measured data. NSE can range from - $\infty$ to 1 and an efficiency of 1 indicates a perfect match between observed and simulated discharges. NSE value between 0.9 and 1 indicate that the model performs very well while values between 0.6 and 0.8 indicate the model performs well (Abeyou Wale, 2008).

The efficiency, E proposed by Nash and Sutcliffe (Nash, 1970) is defined as one minus the sum of the absolute squared differences between the predicted and observed values normalized by the variance of the observed values during the period under investigation.

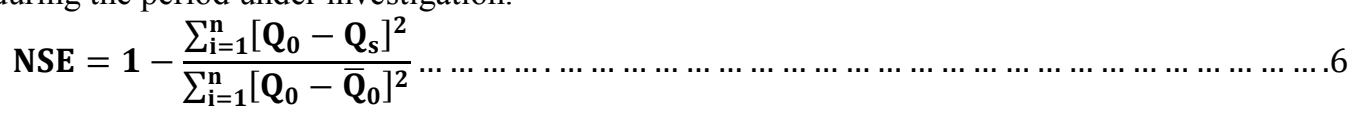

Where, $\mathrm{Q}_{0}=$ observed flow, $\mathrm{Q} s=$ Simulated flow and $\overline{\varphi_{0}}=$ Average of observed flow

Moriasi et al (2007) recommended for monthly time steps that NSE values between 0.75 and 1 is very good and NSE-value between 0.65 and 0.75 is good.

According to (Motovilov Y.G., 1999), the NSE values can vary from 0 to 1, with 1 indicating a perfect fit of the data. According to common practice, simulation results are considered to be good for values of NSE greater than or equal to 0.75 , while for values of NSE between 0.75 and 0.36 the simulation results are considered to be satisfactory.

\section{Coefficient of Determination, $\mathbf{R}^{2}$}

The coefficient of determination $\mathrm{R}^{2}$ is defined as the squared value of the coefficient of correlation. It is estimated as

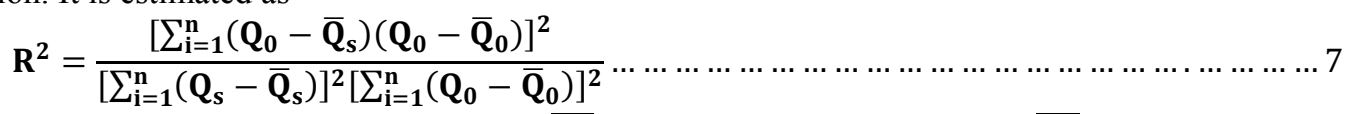

Where, $\mathrm{Q}_{\mathrm{o}}=$ observed flow, $\mathrm{Q}_{\mathrm{s}}=$ Simulated flow, $\overline{Q_{0}}=$ Average of observed flow and $\overline{Q_{\bar{q}}}=$ Average of simulated flow.

\section{Percent Difference, D}

The percent difference for a quantity (D) over a specified period with total days calculated from measured and simulated values of the quantity in each model time step as:

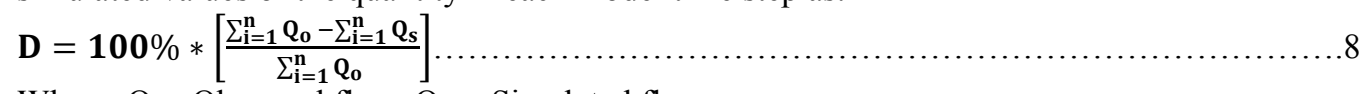

Where, $Q_{0}=$ Observed flow, $Q_{\mathrm{s}}=$ Simulated flow

The percent difference (D) can vary between $\infty$ and $-\infty$ but it performs best when a value of 0 (zero) is generated. A percent difference between $+5 \%$ or $-5 \%$ indicates that a model performs well while percent difference between $+5 \%$ and $+10 \%$ and $-5 \%$ and $-10 \%$ indicates a model with reasonable performance (Abeyou Wale, 2008).

\section{RESULTS AND DISCUSSION}

\subsection{HEC-HMS Model Calibration and Validation Results}

In this research, among the existing methods in the model, the Nelder and Mead Method (NM) and the sum of squared residuals measure for goodness of fit have been applied for calibrating the model. Model calibration and validation were done for Didessa sub-basin and Fincha sub-basin at selected gauging station depending on different criteria. Didessa gauging and little anger were used for Didessa sub-basin where as Neshi and Fincha gauging station were used for Fincha sub-basin. The 10- years of observed flow time-series data (1991 - 2000) of Fincha Sub-basin selected station have been used for model calibration whereas 5- years of observed flow time-series data (2001 - 2005) of the same stations was used Model validation. Due to data limitation and inconsistency in Didessa sub-basin only 7-years of observed flow time-series data (1985 - 1991) and 5-years of observed flow time-series data (1992 - 1996) of the selected station have been used for model calibration and Validation respectively. Then the model shows good result at little anger and Fincha station for Didessa and Fincha Sub-basin respectively so 
that the parameters optimized at these stations were used for flow simulation.

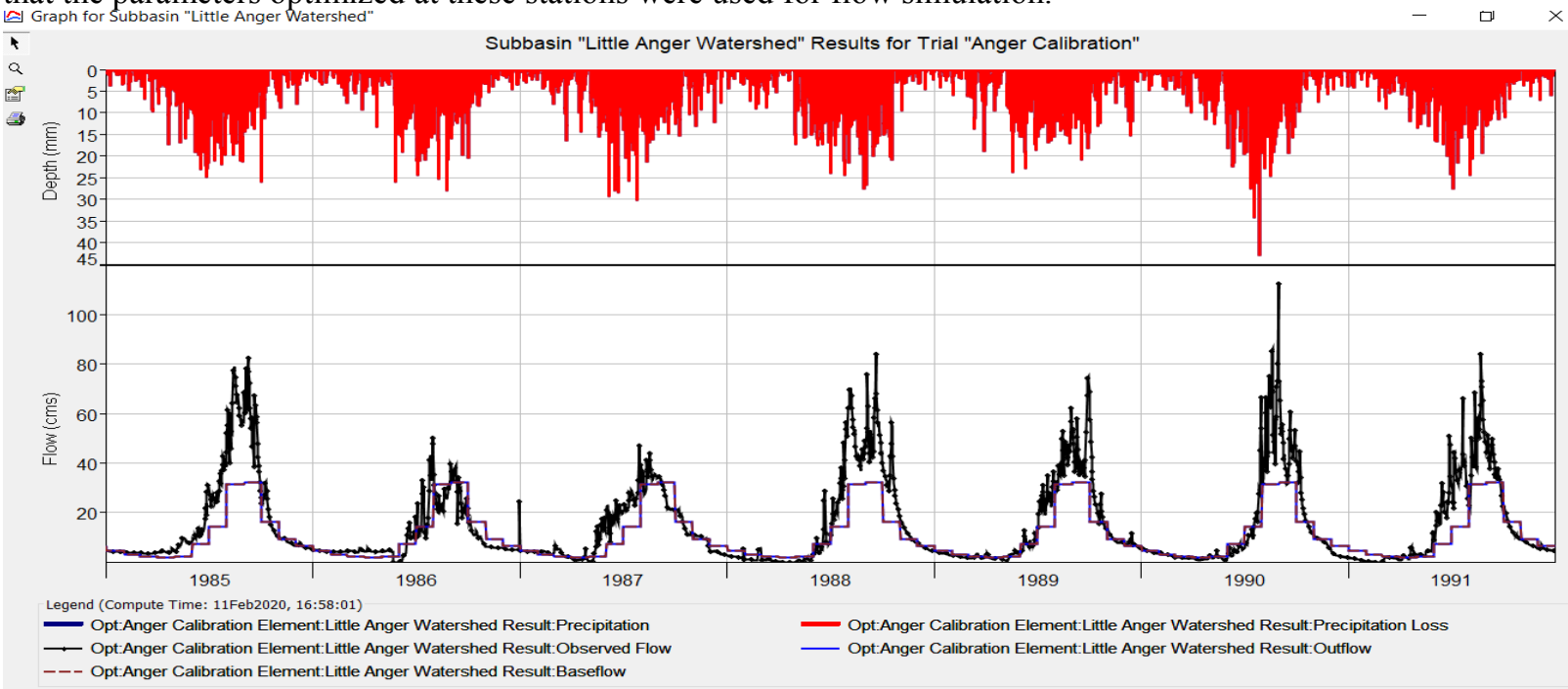

Figure 9: Daily Simulated flow Hydrograph Calibrated and Observed flow at Little Anger Station Comparison (1991-2000).

The results of the performance evaluation criteria of the HEC-HMS model are summarized in tabular form as shown in Table 3, 4, and 5 for Dabus, Didessa and Fincha sub-basin respectively.

Table 3: Performance indices of model during Calibration and Validation of Didessa sub basin.

Indices

\begin{tabular}{ccc} 
& \multicolumn{2}{c}{ DidessaGauge Nr Arjo } \\
& Calibration & Validation \\
NSE & 0.55 & 0.27 \\
$\mathbf{R}^{2}$ & 0.66 & 0.41 \\
$\mathbf{D}$ & 3.02 & -2.27
\end{tabular}

\section{Gauging Stations}

\begin{tabular}{cc}
\multicolumn{2}{c}{ Little Anger Gauge } \\
Calibration & Validation \\
0.63 & 0.46 \\
0.75 & 0.77 \\
2.58 & 4.32
\end{tabular}

Table 4: Performance indices of model during Calibration and Validation of Fincha sub basin.

\begin{tabular}{ccc} 
Indices & \multicolumn{3}{c}{ Gauging Stations } \\
\cline { 2 - 4 } & Calibration & Neshi Gauge \\
NSE & 0.58 & Validation \\
$\mathbf{R}^{\mathbf{2}}$ & 0.53 & 0.58 \\
$\mathbf{D}$ & -1.37 & 0.68 \\
\hline
\end{tabular}

The result of Calibration and Validation has revealed a very good simulation performance, satisfactory performance and less performance for all sub basins considered in the this research work. Since all stations shows a very good performance indices in Percent difference /Relative Volume Error (D) due to the great difference in other two performance indices only the parameters optimized at the Dabus gauge, Didessa gauge and Neshi gauge were used for flow simulation(water availability assessment) in Dabus, Didessa and Fincha sub basin respectively. For the other gauging stations the Hydrograph results of Calibration and Validation was shown in Appendix A.

\subsection{Water Availability}

\subsubsection{Didessa Sub-Basin}

The water availability of Didessa sub basin was assessed as sub-basin level and small watershed depending on the importance of the watershed and availability of gauging stations that were used for model calibration and validation. So the water availability in Didessa Sub basin was assessed for the whole sub-basin at out let and small catchment like Didessa watershed around Arjo, Dabana Watershed and Little anger watershed. The water availability shown by Figure 10 and 11 on average monthly basis and annual basis

The flow components of the sub-basin were also separated at considered watershed in the sub-basin. The result shows that the high percentage of flow was occupied by Direct Runoff in the considered watershed. So this needs effective management of water resources in the sub-basin to utilize effectively. Table 5 shows the annual flow components and its percentage. 


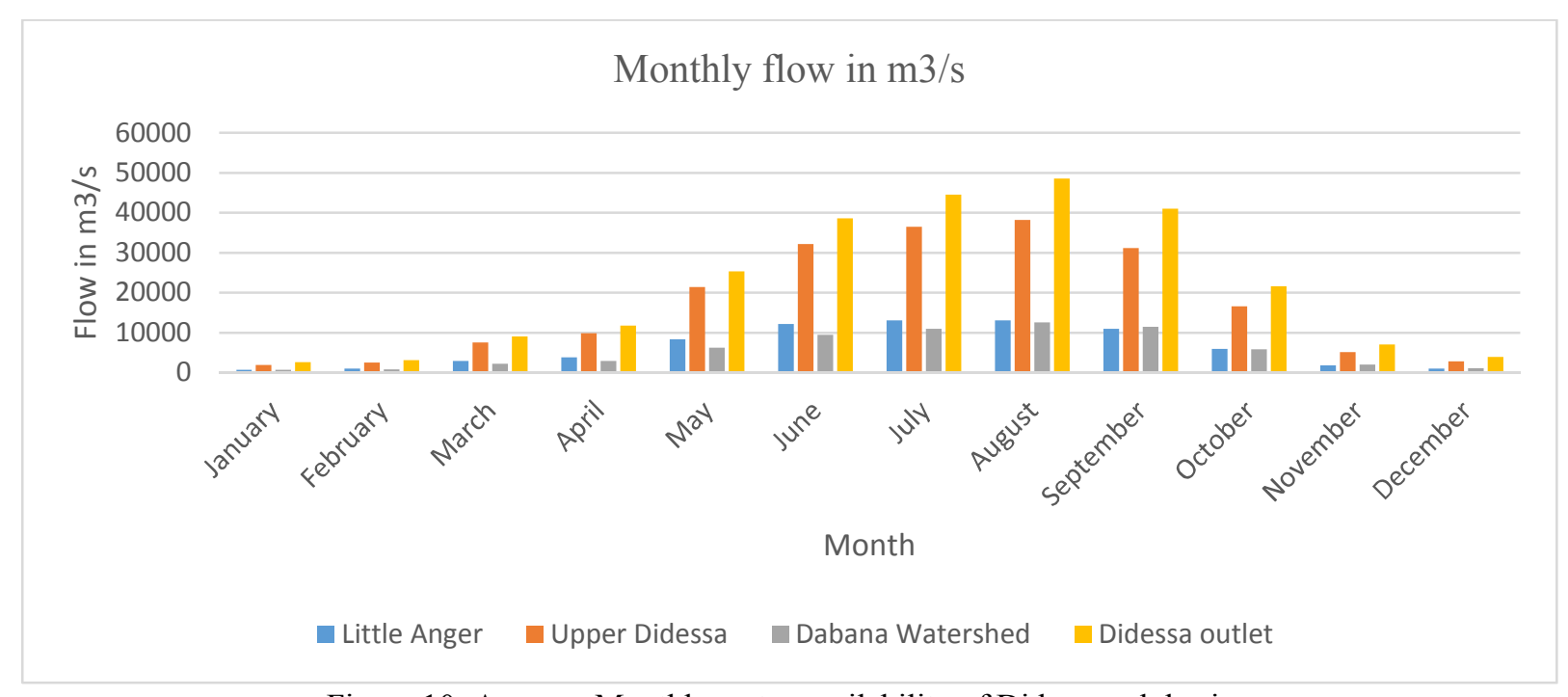

Figure 10: Average Monthly water availability of Didessa sub basin

Table 5: Budget component quantities for all Watershed in the sub-basin of 32 years

\begin{tabular}{|c|c|c|c|c|c|c|c|c|}
\hline Sub Watershed & $\begin{array}{l}\text { Total Rainfall } \\
\text { (mm/year) }\end{array}$ & $\begin{array}{l}\text { Evaporation } \\
\text { (mm/year) }\end{array}$ & $\begin{array}{l}\text { Deep } \\
\text { percolation } \\
\text { (mm/year) }\end{array}$ & $\begin{array}{l}\text { Direct } \\
\text { Runoff } \\
\text { (mm/year) }\end{array}$ & $\begin{array}{l}\text { Baseflow } \\
\text { (mm/year) }\end{array}$ & $\begin{array}{l}\text { Totalflow } \\
\text { (mm/year) }\end{array}$ & $\begin{array}{l}\text { Percetage } \\
\text { of base } \\
\text { flow }(\%)\end{array}$ & $\begin{array}{l}\text { Percetage } \\
\text { of Direct } \\
\text { flow }(\%)\end{array}$ \\
\hline Little Anger & 56824.55 & 14080.26 & 2765.67 & 2269795.80 & 126878.90 & 2396674.70 & 5.29 & 94.71 \\
\hline Upper Didessa & 56824.55 & 14080.26 & 2765.43 & 5930908.50 & 659689.60 & 6590673.70 & 10.01 & 89.99 \\
\hline Dabana Watershed & 56824.55 & 14080.26 & 2765.43 & 1688142.80 & 438257.60 & 2126391.90 & 20.61 & 79.39 \\
\hline
\end{tabular}

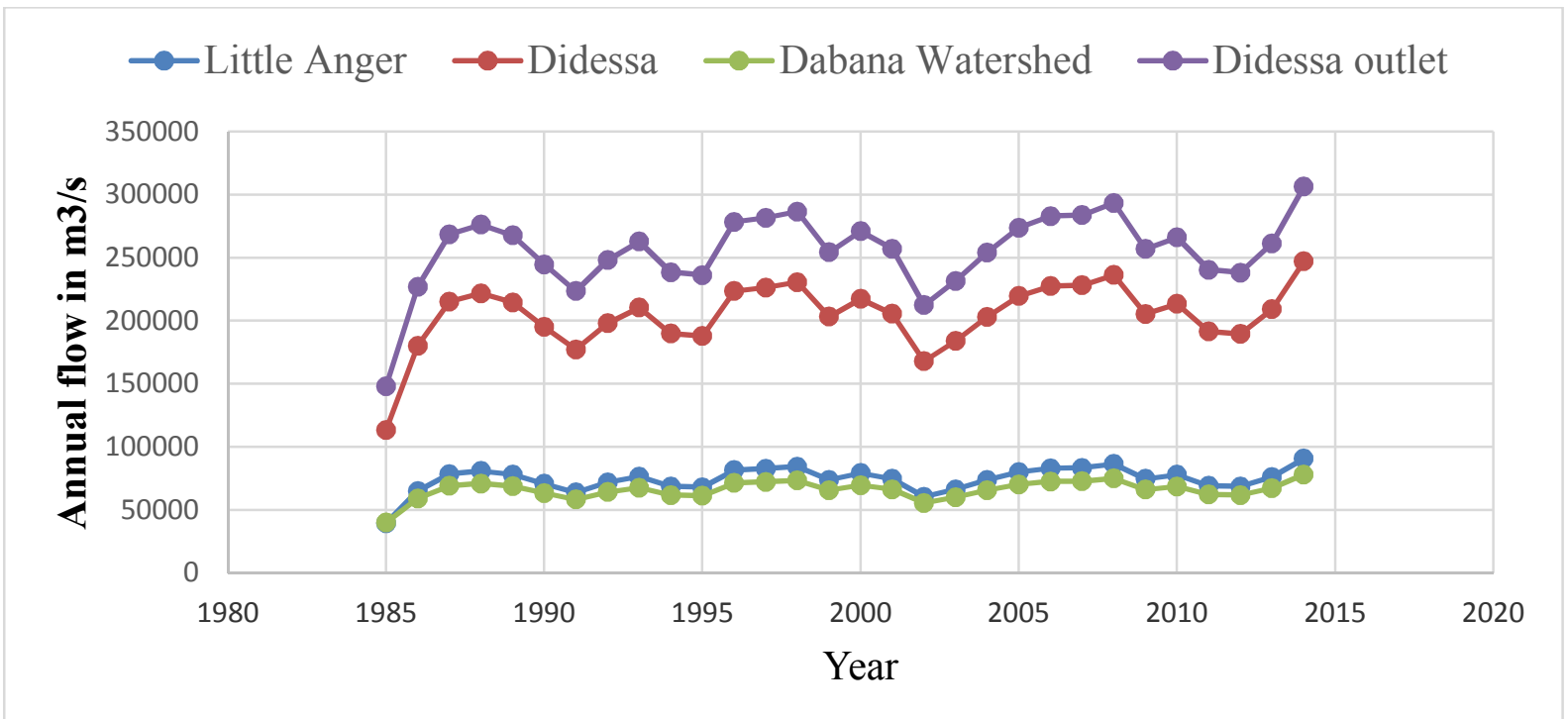

\subsubsection{Fincha Sub-Basin}

Figure 11: Annual water availability of Didessa sub basin

The water availability of Fincha sub basin was also assessed as sub-basin level and small watershed. So the water availability in Fincha Sub basin was assessed for the whole sub-basin at outlet and small catchment like Nesh watershed and upper Fincha watershed. The result of Water availability shown by Figure 12 and 13 on average monthly basis and annual basis

The flow components of the sub-basin were also separated at considered watershed in the sub-basin. The result shows that the high percentage of flow is occupied by Direct Runoff in the considered watershed. So this is indication excess water availability in the sub-basin which was not yet effectively utilized except for Fincha Hydropower generation and Amert Neshi multi irrigation. Table 6 shows the annual flow components and its percentage. 


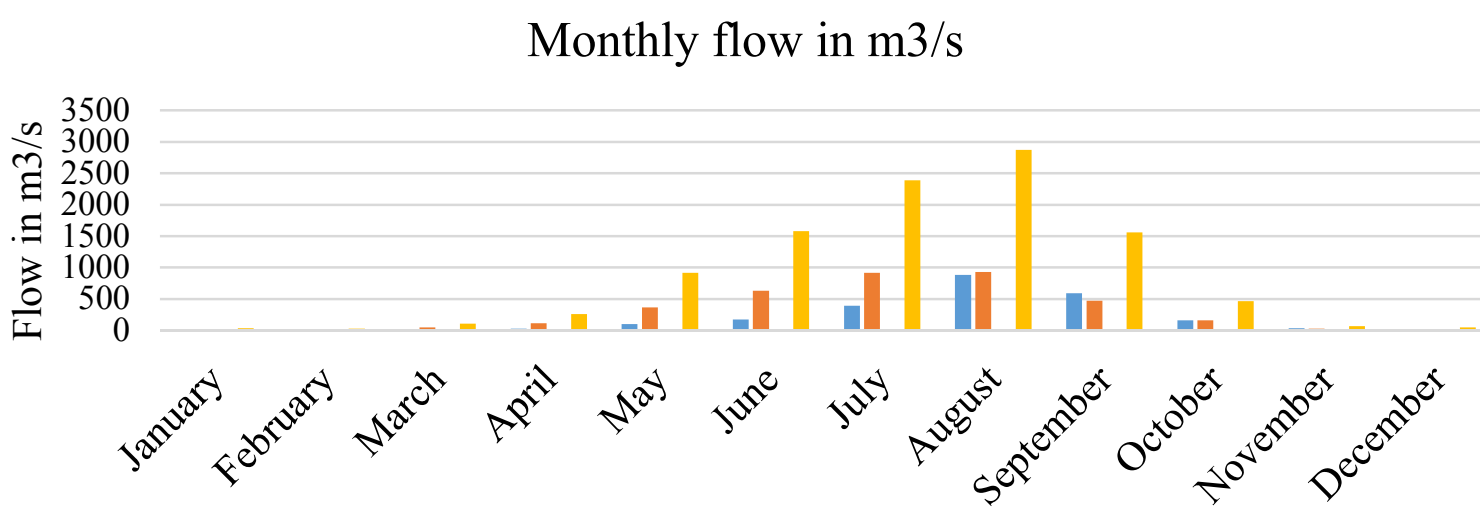

Month

Neshi $\quad$ Fincha Fincha outlet

Figure 12: Average Monthly water availability of Fincha sub basin

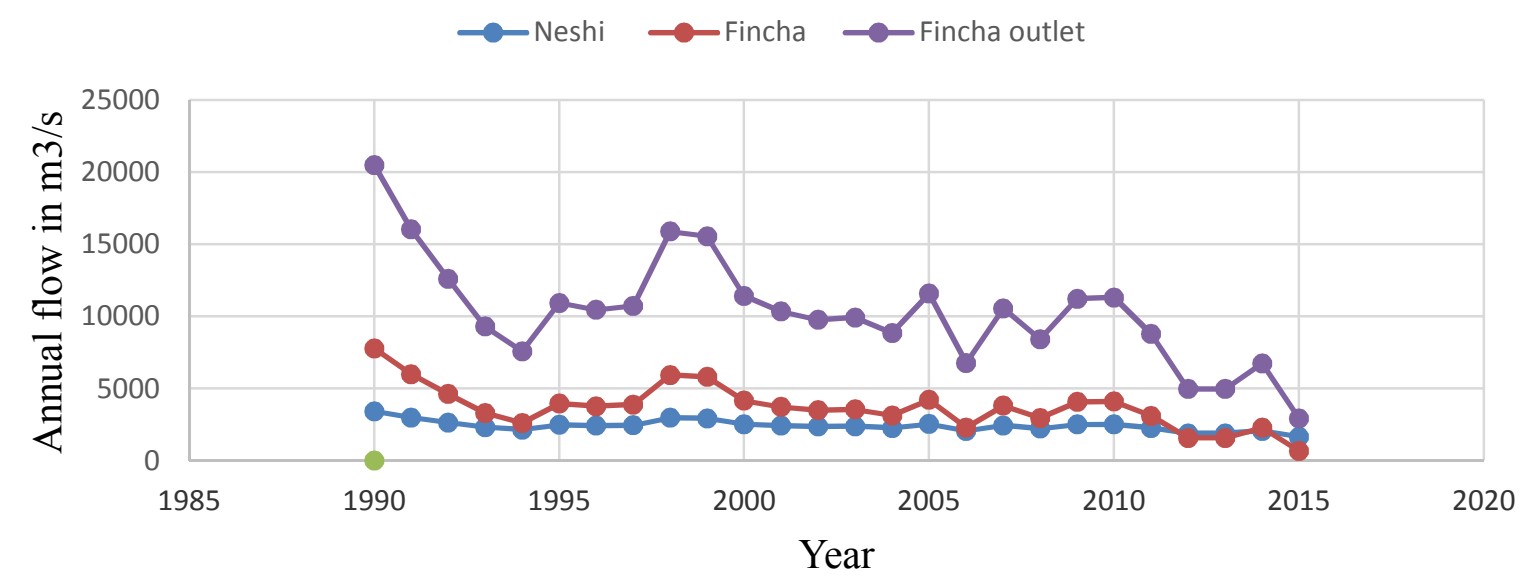

Figure 13: Annual water availability of Fincha sub basin

Table 6: Budget component quantities for all Watershed in the sub-basin of 26 years

\begin{tabular}{|c|c|c|c|c|c|c|c|c|}
\hline Sub Watershed & $\begin{array}{c}\text { Total } \\
\text { Rainfall } \\
\text { (mm/year) }\end{array}$ & $\begin{array}{c}\text { Evaporation } \\
\text { (mm/year) }\end{array}$ & $\begin{array}{c}\text { Deep } \\
\text { percolation } \\
\text { (mm/year) }\end{array}$ & $\begin{array}{l}\text { Direct Runoff } \\
\text { (mm/year) }\end{array}$ & $\begin{array}{l}\text { Baseflow } \\
(\mathrm{mm} / \text { year) }\end{array}$ & $\begin{array}{c}\text { Totalflow } \\
\text { (mm/year) }\end{array}$ & $\begin{array}{c}\text { Percetage } \\
\text { of base } \\
\text { flow (\%) }\end{array}$ & $\begin{array}{l}\text { Percetage } \\
\text { of Direct } \\
\text { flow (\%) }\end{array}$ \\
\hline Neshi & 41025.05 & 0.55 & 35362.93 & 21671.18 & 41601.75 & 63272.93 & 65.75 & 34.25 \\
\hline Fincha & 41021.79 & 0.55 & 35362.69 & 32129.59 & 35538.61 & 67663.90 & 52.52 & 47.48 \\
\hline
\end{tabular}

\section{CONCLUSIONS AND RECOMMENDATIONS}

\subsection{Conclusions}

The study of water resources availability of Fincha and Didessa is highly requires emphases. In the research HECHMS model was used for water resource availability assessment which show good and satisfactory performance on different gauging stations considered in this research work.

The result of Water resources availability assessment shows that high percentage of flow occupied by Direct Runoff for both sub basins respectively. So the available water in the sub-basins should be managed and planned for fair allocation and effective utilization of the country water resources.

\subsection{Recommendations}

From the result of the research, the following are highly recommended for further studies of the sub-basins water resources allocation. 
1. The swamp located in the sub-basins should be well investigated to determine their contribution for the water resources allocation.

2. Water Resources allocation studies should be conducted by considering the swamp, existing project and planned project for different purposes.

\section{References}

[1]. Abeyou Wale. (2008). Hydrological balance of lake tana upper blue nile,Ethiopia. Internation Institution for Geo-informatics and Earth observation.

[2]. William A. Scharffenberg and Matthew J.Fleming. (2010). Hydrologic Modelling System. In U. A. Engineer. Washington DC, 20134-1000: US Army Corps of Engineer.

[3]. Awulachew, A. D. (2009). Characterization and Atlas of the Blue Nile Basin. International Water Management Institute.

[4]. Engineer, U. A. (2007). HEC-ResSim-Reservoir System Simulation. In U. A. Engineer, HEC-ResSimReservoir System Simulation. US Army corps of Engineer, Institute of water Resources, Hydrological Engineering Center.

[5]. Engineer, U. A. (2010). Hydrologic Modeling System HEC-HMS. In US Army corps of Engineer. US Army corps of Engineer,Institute of water resources HEC.

[6]. Engineer, U. S. (2000). Hydrologic Modelling System HEC HMS Technical Reference manual. United State Arms Corps of Engineer Institute of water resources.

[7]. Motovilov Y.G., G. L. (1999). Regional model of hydrological cycle.Application to the NOPEX region. Department of Geophysics, University of Oslo.

[8]. MoWR, F.-E. (2002). DABUS MEDIUM HYDROPOWER PROJECT. Addis Ababa.

[9]. O. Munyaneza1, A. M. (2014). Assessment of surface water resources availability using catchment modelling and the results of tracer studies in the mesoscale Migina Catchment, Rwanda. Hydrology and Earth Science System.

[10].Piggott, A. S. (2005). Piggott, A.R., S. MoinA revised approach to the UKIH method for the calculation of baseflow,. Hydrological Sciences Journal, 911-920.

[11]. Simonovic, L. L. (2009). Streamflow Forecast and Reservoir Operation. Water Resour Manage (2010) 24:83104.

[12].Singh, A. I. (2011). Streamflow Response to Climate Change. Water Resource Management (2012) 26:14091424.

[13]. Sloto, R. a. (1996). HYSEP: A computer program for streamflow hydrograph separation and analysis: U.S. Geological Survey Water-Resources Investigations Report 96-4040, 46 p.

[14].US Army corps of Engineer. (2010). Hydrologic Modeling System HEC-HMS. In US Army corps of Engineer. US Army corps of Engineer,Institute of water resources HEC.

[15].US Army corps of Engineer, H. E. (2010,Version 5). In HEC-GeoHMS, Geospatial Hydrologic Modelling Extension. US Army Corps of Engineers.

[16]. World Meteorological Organization, W. (2012). TECHNICAL MATERIAL FOR WATER RESOURCES ASSESSMENT. World Meteorological Organization. 